\title{
Dry-pressing preparation of mullite columnar structure using waste gangue during firing and its properties
}

\author{
Weixia DONG ${ }^{\dagger}$, Qifu BAO, Xingyong GU ${ }^{\ddagger}$, Huijuan SHEN and Jingwei YANG \\ Jingdezhen Ceramic Institute, Jingdezhen 333001, P. R. China
}

\begin{abstract}
The mullite columnar structure are prepared by a dry-press method using waste gangue substituted for kaolin clay. The properties e.g., water absorption, bulk density and bending strength of the samples fired at the temperature range of $1300-1550^{\circ} \mathrm{C}$ are studied. The microstructure of mullite columnar structures are characterized by X-ray diffraction and field emission scanning electron microscopy with an energy dispersive $\mathrm{X}$-ray spectroscopy. The results reveal that waste gangue substituted for the kaolin is available for mullite columnar structure. Impurities in waste gangue e.g., $\mathrm{TiO}_{2}$ and $\mathrm{Fe}_{2} \mathrm{O}_{3}$ lower the formation temperature of mullite columnar structure, which endow the samples with high refractoriness. Due to the presence of interlocking structure constructed by mullite crystals, the sample achieves the optimum bending strength of $97.6 \mathrm{MPa}$ at the temperature of $1400^{\circ} \mathrm{C}$, which is future application in refractory materials. The dry-pressed preparation method provides a simple way to synthesize mullite columnar structure using waste gangue substituted for kaolin clay that can be future applied in lightweight refractory industry. (C2017 The Ceramic Society of Japan. All rights reserved.
\end{abstract}

Key-words : Mullite columnar structure, Dry-pressing method, Waste gangue, Bending strength

[Received November 10, 2016; Accepted November 29, 2016]

\section{Introduction}

Due to the high thermal stability and excellent mechanical properties, mullite materials have been widely used in areas like ceramics, metallurgy, construction, etc. ${ }^{1)}$ Mullite with a general formula $\mathrm{Al}_{4+2 x} \mathrm{Si}_{2-2 x} \mathrm{O}_{10-x}(0.18 \leq x \leq 0.82)$ is in fact a solid solution of aluminum silicate and alumina, which is usually incorporated by a large variety of foreign ions in raw materials, such as $\mathrm{Ti}^{4+}, \mathrm{Ti}^{3+}, \mathrm{Fe}^{3+}, \mathrm{Mg}^{2+}, \mathrm{Ca}^{2+}, \mathrm{K}^{+}$and $\mathrm{Na}^{+}$. ${ }^{2)}$ Small quantity of impurities in raw materials (e.g. titanium/iron/ alkaline oxides) as foreign ions are considered to facilitate mullite formation through accelerating the dissolution of aluminosilicate. ${ }^{3)}$ However, too many impurities could disturb the stable structure of mullite, which may be lower the melting temperature and refractory properties of mullite. Kaolin as the natural raw material has been widely used for the preparation of mullite, due to its small quantity of impurities and its lower cost than those of $\mathrm{Al}_{2} \mathrm{O}_{3}$ and $\mathrm{SiO}_{2}{ }^{3), 4)}$ However, the wide application of high purity kaolin as natural material is limited due to its low abundance in the recent years. ${ }^{4), 5)}$ Thus, it is an interesting topic to explore alternative inexpensive raw materials with desirable structure characteristics for the formation of mullite. Waste gangue, the byproducts of coal and thermal power plant, has similar chemical compositions with those of kaolin. ${ }^{6)-11)}$ Therefore, it is highly prospective and would be the perfect substitute for the kaolin to be used in mullite materials. However, to our knowledge, the preparation of mullite columnar structure has not been reported using waste gangue by a dry-press method. In the present work, we have reported the dry-pressing preparation of the mullite columnar structure using waste gangue as main materials. In order to optimize the microstructure (e.g. the ideal mullite length diameter ratio, content and distribution) after firing, effects of the firing temperature on the properties of mullite columnar structure has

\footnotetext{
$\dagger$ Corresponding author: W. Dong; E-mail: weixia_dong@sina.com

* Corresponding author: X. Gu; E-mail: guxing-y@163.com
}

been discussed.

\section{Experimental section}

Chemical composition, as determined by X-Ray Fluorescence (XRF) as shown in Table 1. All the materials in Table 1 were powders. The other chemicals are analytical grade.

The mullite precursor composition was prepared by mixing $73.79 \mathrm{wt} . \%$ waste gangue and $26.21 \mathrm{wt} . \% \mathrm{Al}_{2} \mathrm{O}_{3}$ with the addition of mineralized $\left(2 \% \mathrm{~V}_{2} \mathrm{O}_{5}, 1 \% \mathrm{MnO}_{2}\right.$ and $\left.3 \% \mathrm{AlF}_{3}\right)$, named as CSK powder. Batches were prepared by drying mill for 30 min. The grinding material was alumina ball. The sieved powder was to pass 80 mesh and granulated with $6 \%$ water, then aged for $24 \mathrm{~h}$. The processed powder was uniaxially pressed under $20 \mathrm{MPa}$ in a steel mold. The samples were put in the oven to dry at $90^{\circ} \mathrm{C}$, followed by placing them on the alumina rollers of an electric furnace to heat at a heating rate of $3^{\circ} \mathrm{C} / \mathrm{min}$ for $3 \mathrm{~h}$. Samples with rectangular shape of $70 \times 10 \times 10 \mathrm{~mm}$ were prepared for the bending strength test.

\subsection{Characterization}

The sintering properties of the fired samples was evaluated based on the Archimedes principle. The water absorption, $\mathrm{W}_{\mathrm{a}}$ $(\%)$, open porosity, $\mathrm{P}_{\mathrm{a}}(\%)$ and bulk density, $\mathrm{D}_{\mathrm{b}}\left(\mathrm{g} / \mathrm{cm}^{3}\right)$ of the samples was determined according to Eqs. (1)-(3) by boiling samples in water for $3 \mathrm{~h}$, followed by immersing them in water for $24 \mathrm{~h}$ at ambient temperature.

Table 1. Chemical analysis of the raw materials

\begin{tabular}{cccccccccc}
\hline $\begin{array}{c}\text { Raw } \\
\text { Material }\end{array}$ & $\begin{array}{c}\mathrm{Al}_{2} \mathrm{O}_{3} \\
\%\end{array}$ & $\begin{array}{c}\mathrm{SiO}_{2} \\
/ \%\end{array}$ & $\begin{array}{c}\mathrm{TiO}_{2} \\
/ \%\end{array}$ & $\begin{array}{c}\mathrm{K}_{2} \mathrm{O} \\
/ \%\end{array}$ & $\begin{array}{c}\mathrm{Na}_{2} \mathrm{O} \\
/ \%\end{array}$ & $\begin{array}{c}\mathrm{CaO} \\
/ \%\end{array}$ & $\begin{array}{c}\mathrm{MgO} \\
/ \%\end{array}$ & I.L & Total \\
\hline $\begin{array}{c}\text { waste } \\
\text { gangue }\end{array}$ & 26.68 & 65.21 & 1.24 & 3.16 & 0.43 & 0.3 & 0.84 & 16.7 & 99.61 \\
$\begin{array}{c}\text { Calcined } \\
\text { alumina }\end{array}$ & $>99.0$ & $<0.4$ & $<0.1$ & a little a little a little & - & - & 100.00 \\
\hline
\end{tabular}




$$
\begin{aligned}
& \mathrm{W}_{\mathrm{a}}=\left(\mathrm{M}_{1}-\mathrm{M}_{\mathrm{o}}\right) / \mathrm{M}_{\mathrm{o}} * 100 \% \\
& \mathrm{~Pa}=\left(\mathrm{M}_{1}-\mathrm{M}_{\mathrm{o}}\right) /\left(\mathrm{M}_{1}-\mathrm{M}_{2}\right) * 100 \% \\
& \mathrm{D}_{\mathrm{b}}=\mathrm{M}_{\mathrm{o}} \rho_{\mathrm{w}} /\left(\mathrm{M}_{1}-\mathrm{M}_{2}\right)
\end{aligned}
$$

Where $\mathrm{M}_{0}, \mathrm{M}_{1}$ and $\mathrm{M}_{2}$ are the mass of the dry, wet sample in air and wet sample in water, respectively. $\rho_{\mathrm{w}}$ is the constant bulk density $\left(1 \mathrm{~g} / \mathrm{cm}^{3}\right)$ of water. The calculated values were averaged from five samples.

The crystal phase of the samples were characterized by X-ray diffraction (XRD, PANalytical X'Pert Pro, Holland) in a $2 \theta$ range from 5 to $70^{\circ}$ by using $\mathrm{Cu}-\mathrm{K} \alpha$ radiation $(\lambda=0.15420 \mathrm{~nm})$ operating at $50 \mathrm{kV}$ and $40 \mathrm{~mA}$. The investigation of the microstructures and compositions of the sample powders was done by field emission scanning electron microscopy (FESEM, KYKYEM3900, China) with an energy dispersive X-ray spectroscopy (EDS) system operating at an accelerating voltage of 5.0 or 15.0 $\mathrm{kV}$. Etching solution like hydrofluoric acid solution was used to remove the glassy surface of the fired sample, so that the morphology of the crystal can be revealed. Moreover, XRF (PANalytical B.V., Holland) was used to analyze the chemical composition of the coal. The bending strength of the rectangularshaped tested samples was studied with the help of the Test Machine (Shenzhen Reger Instrument Co. Ltd. China). The chemical and physical changes of the samples during heating were evaluated by a thermal gravimetry-differential scanning calorimeter. (TG-DSC, Netzsch Scientific Instruments Trading Ltd., Germany).

\section{Results and discussion}

\subsection{Mineralogical, morphological, and chemical characteristics of waste gangue}

Gangue produced from Jiangxi province Pingxiang city is hard due to the presence of coal in the clay. The appearance of gangue sample before calcination is shown in Fig. 1(a). the black shadows in the picture suggested that those were the residual black coal, and would become white after calcination as the coal
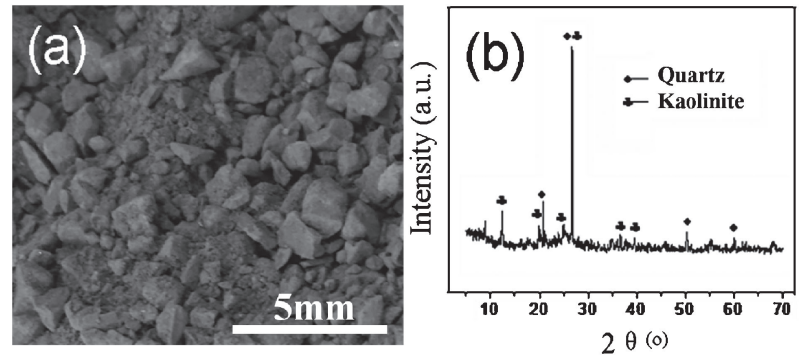

Fig. 1. Appearance (a) and XRD pattern (b) of waste gangue sample. was moved from the sample. The gangue sample is made up of quartz and kaolin [Fig. 1(b)]. Table 1 gives the different compositions of the gangue and calcined alumina.

\subsection{Thermal analysis}

Figure 2 shows TG-DSC analysis of CSK powder (room temperature to $1400^{\circ} \mathrm{C}$ ). From Fig. 2, during temperature range of 30 to $200^{\circ} \mathrm{C}$, the absorbed water is evaporated, resulting in $2.52 \%$ of weight loss of the samples. The flammable substances in the samples burn during the temperature range of 250 to $320.4^{\circ} \mathrm{C}$, which would result in a larger weight loss of about $18.04 \%$. From 448.8 to $1140^{\circ} \mathrm{C}$, structural hydroxyl groups are removed from the samples with a weight loss of $8.25 \%$.

\subsection{Sintering and mechanical properties}

Figure 3 shows that water absorption (Wa), open porosity (Pa) and bulk density $\left(\mathrm{D}_{\mathrm{b}}\right)$ of the samples prepared at different temperatures. It is observed in Fig. 3 that with the increase of the temperature, the $\mathrm{D}_{\mathrm{b}}$ increases, whereas $\mathrm{Wa}$ and $\mathrm{Pa}$ of the samples decrease. This is mainly due to the densification of the mixture as the low eutectic point melt of $\mathrm{K}_{2} \mathrm{O}, \mathrm{CaO}, \mathrm{Fe}_{2} \mathrm{O}_{3}$ and $\mathrm{TiO}_{2}$ with $\mathrm{SiO}_{2}-\mathrm{Al}_{2} \mathrm{O}_{3}$ binary system produce viscous liquid phase of the mixture. When the temperature rises, $\mathrm{Wa}$ and $\mathrm{Pa}$ are lowered due to the accelerated viscous flow. At $1400^{\circ} \mathrm{C}$, Wa and $\mathrm{Pa}$ of the samples reach the lowest values of 0.26 and $0.47 \%$, respectively. Further increased the temperature of $1550^{\circ} \mathrm{C}$, Wa and $\mathrm{Pa}$ increase indicating that the samples are overfired. This phenomenon is mainly because of the conversion of $\mathrm{Fe}_{2} \mathrm{O}_{3}$ to $\mathrm{Fe}_{3} \mathrm{O}_{4}$ with $\mathrm{O}_{2}$ generation, resulting in the slight volume expansion and thus lowering the $\mathrm{D}_{\mathrm{b}}$ of the samples as well.7)

Figure 4 shows the bending strength of samples prepared at various firing temperatures. From 1300 to $1450^{\circ} \mathrm{C}$, the bending

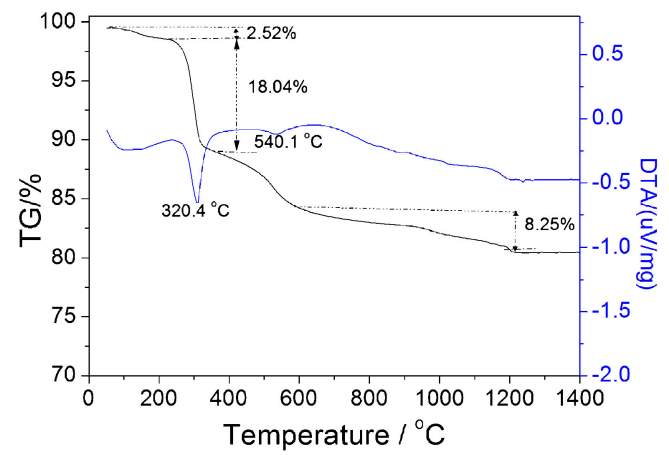

Fig. 2. TG-DSC analysis of CSK powder (room temperature to $\left.1400^{\circ} \mathrm{C}\right)$.
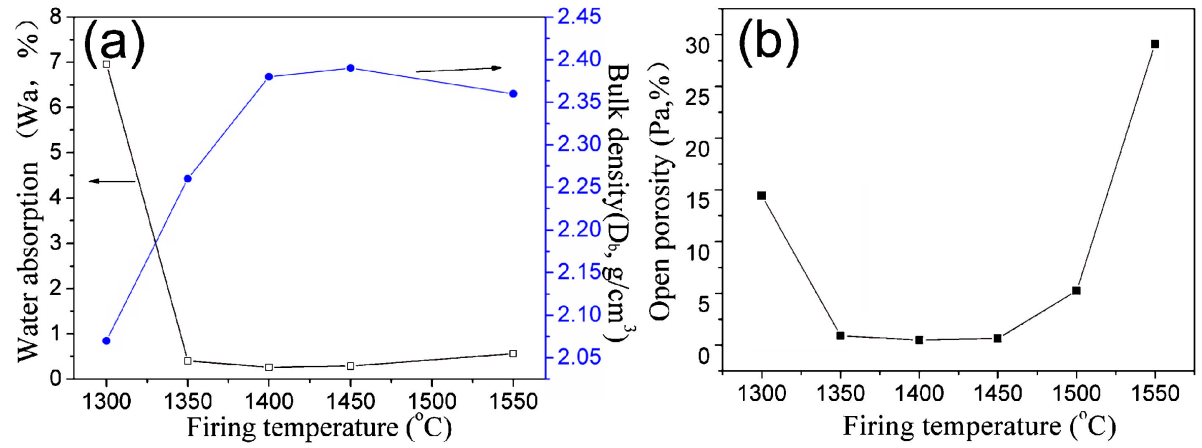

Fig. 3. Water absorption (Wa), open porosity $(\mathrm{Pa})$ and bulk density $\left(\mathrm{D}_{\mathrm{b}}\right)$ of the samples prepared at various temperatures. 


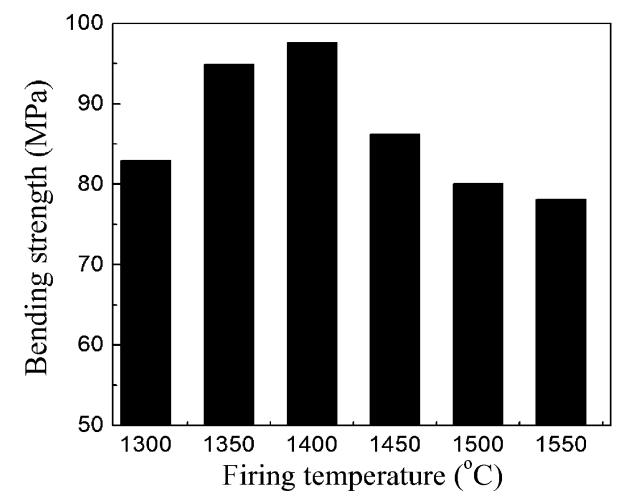

Fig. 4. Bending strength of the samples prepared at various temperatures.

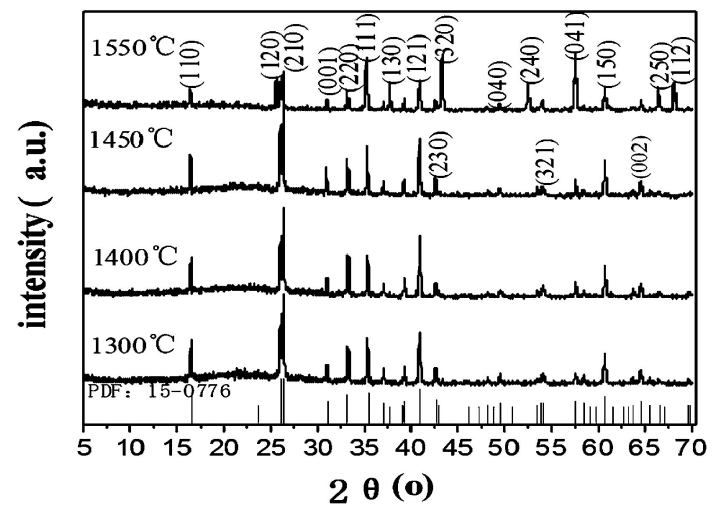

Fig. 5. XRD patterns of the samples at various temperatures.

strength of the sample increases. However, when firing temperature further increases to $1550^{\circ} \mathrm{C}$, the bending strength of the sample drops drastically due to the microstructural evolution within the samples. This will be elaborated more in the following section.

\subsection{Phase and micro structural evolution}

Figure 5 shows the XRD patterns of the samples prepared at various firing temperatures. When the firing temperature is $1300^{\circ} \mathrm{C}$, the sample can be assigned to a pure mullite phase (JCPDS files No. 15-0776). The peak intensity of mullite phase further increases with increase of the firing temperature. The strong and sharp reflection peaks in the diagram shows well crystallization in the samples. However, further increasing the firing temperature to $1550^{\circ} \mathrm{C}$, the peak intensities of the mullite phase decreases.

Figure 6 shows the FESEM images of the fractured surface of the samples prepared at different firing temperatures. From the morphologies of the samples, the columnar structure of the crystals can be distinguished. When the firing temperature is $1400^{\circ} \mathrm{C}$, the columnar mullite crystals grow more acicular and longer than those of the sample at $1300^{\circ} \mathrm{C}$ due to the increasingly fluid alkali-rich silicate liquid in which it is located to facilitate mass transport and crystal growth. ${ }^{7)-9)}$ And there are some isolated spherical pores existing in the fractured surface of the samples, which indicates the existence of the liquid phase and the viscous flow mechanism. The existence of viscous flow can also be verified from the EDS analysis related to the morphology shown in Fig. 7 with the content of the detected elements collected in Table 2. It can be seen that apart from the dominant
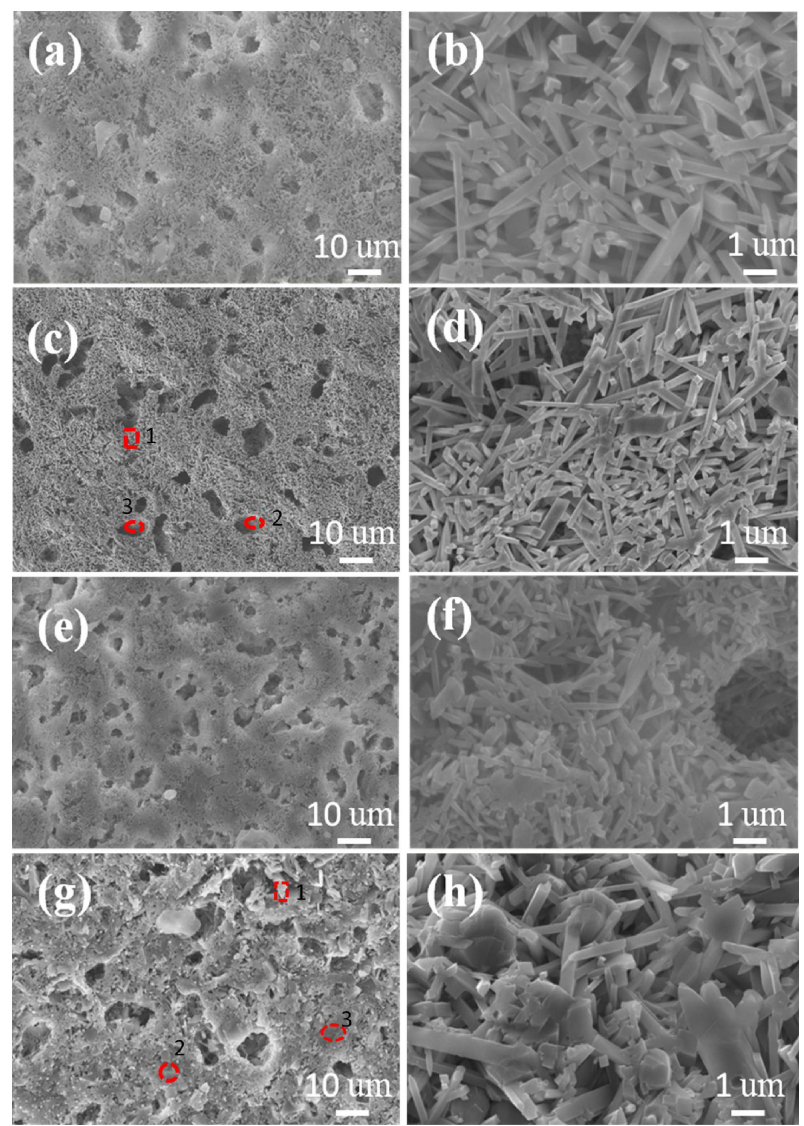

Fig. 6. FESEM images of the fractured surface of the samples prepared at various temperatures: (a, b) $1300^{\circ} \mathrm{C},(\mathrm{c}, \mathrm{d}) 1400^{\circ} \mathrm{C},(\mathrm{e}, \mathrm{f}) 1450^{\circ} \mathrm{C}$, $(\mathrm{g}, \mathrm{h}) 1550^{\circ} \mathrm{C}$.
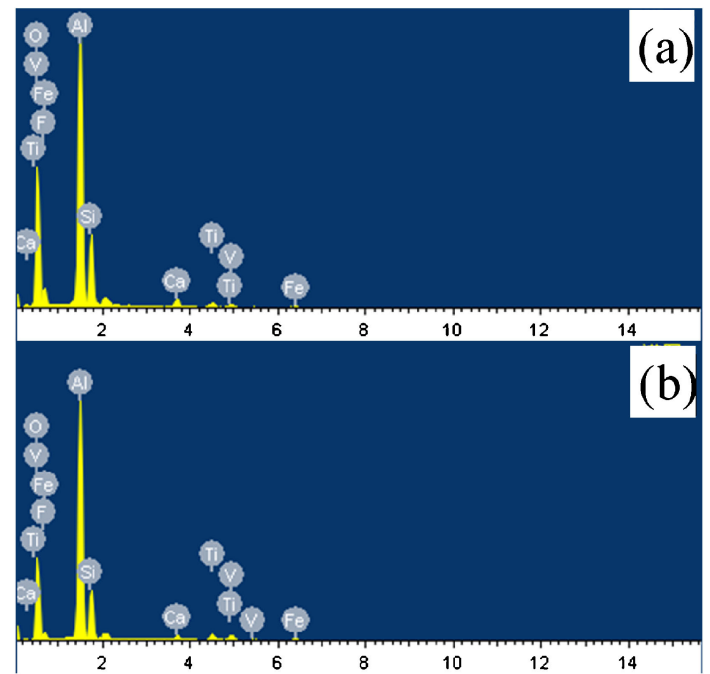

Fig. 7. EDS mappings of the samples fired at various temperatures: (a) $1400^{\circ} \mathrm{C}$, (b) $1550^{\circ} \mathrm{C}$

elements of $\mathrm{Al}, \mathrm{Si}$ and $\mathrm{O}$ elements, the glass around the mullite crystals contains elements of $\mathrm{Ca}, \mathrm{Fe}, \mathrm{V}, \mathrm{F}$ and $\mathrm{Ti}$, indicating the glass phase forms from a liquid containing impurities at firing temperature. The glass phase is enriched in silica due to mullite crystals dissolution above $1400^{\circ} \mathrm{C}$. As a result, the bending strength of the sample increases and reaches the maximum of $97.63 \mathrm{MPa}$ at $1400^{\circ} \mathrm{C}$, the content of liquid phase has signifi- 
Table 2. EDS analysis results of selected spots in Fig. 6

\begin{tabular}{|c|c|c|c|c|c|c|c|c|c|}
\hline Firing temperature & & $\mathrm{O}$ & $\mathrm{Al}$ & $\mathrm{Si}$ & $\mathrm{Ti}$ & $\mathrm{Ca}$ & $\mathrm{Fe}$ & $\mathrm{V}$ & Total \\
\hline \multirow{3}{*}{$1400^{\circ} \mathrm{C}$} & $\begin{array}{l}\text { Spot } 1 \\
\text { (mullite) }\end{array}$ & 26.48 & 34.21 & 39.86 & 0.03 & 0.26 & 0.06 & 0.23 & 100.00 \\
\hline & $\begin{array}{c}\text { Spot } 2 \\
\text { (amorphous phase) }\end{array}$ & 32.38 & 27.56 & 22.71 & 0.06 & 0.32 & 0.39 & 0.21 & 100.00 \\
\hline & $\begin{array}{l}\text { Spot } 3 \\
\text { (amorphous phase) }\end{array}$ & 24.96 & 2.05 & 72.16 & 0.04 & 0.37 & 0.56 & 0.26 & 100.00 \\
\hline \multirow{3}{*}{$1550^{\circ} \mathrm{C}$} & $\begin{array}{l}\text { Spot } 1 \\
\text { (mullite) }\end{array}$ & 24.56 & 17.58 & 40.12 & 0.23 & 0.48 & 0.06 & 0.23 & 100.00 \\
\hline & $\begin{array}{c}\text { Spot } 2 \\
\text { (amorphous phase) }\end{array}$ & 39.66 & 3.16 & 43.55 & 0.57 & 0.47 & 0.26 & 0.12 & 100.00 \\
\hline & $\begin{array}{l}\text { Spot } 3 \\
\text { (amorphous phase) }\end{array}$ & 22.12 & 3.05 & 73.06 & 0.63 & 0.56 & 0.36 & 0.22 & 100.00 \\
\hline
\end{tabular}

cantly increased by extensive incorporation of liquid during firing at $1400^{\circ} \mathrm{C}$, while the viscosity of liquid phase is lowered to eliminate pores and favors the growth of mullite crystals via viscous flow mechanism, ${ }^{9)-11)}$ thus exerting a positive effect on the bending strength of the sample, conversely. In addition, the interlocking texture constructed by mullite crystals also favor the bending strength of the samples. Therefore, the appropriate firing temperature range to prepare mullite materials shall be $1400^{\circ} \mathrm{C}$ in the experiment. As seen in Figs. 6(e) and 6(f), some coarsening mullite crystals with over size are found in the sample fired at $1550^{\circ} \mathrm{C}$. These abnormally-grown columnar mullite crystals may not interlock as efficiently as the smaller ones and thereby the bending strength of the sample is lowered seriously. Different from the mullite crystals coarsening at $1550^{\circ} \mathrm{C}$, the bending strength of the sample at $1450^{\circ} \mathrm{C}$ reduces, which can contribute to the decrease of mullite crystals content and amorphous phase increase according to XRD analysis. It is important to note that, compared to mullite relative content in the sample fired at $1550^{\circ} \mathrm{C}$, there is high mullite content (Fig. 5) and a small amount of the liquid phase is not evenly distributed in the sample fired at $1450^{\circ} \mathrm{C}$ [Figs. $6(\mathrm{e})$ and $6(\mathrm{f})$ ]. Therefore, The bending strength of the sample fired at $1550^{\circ} \mathrm{C}$ reduces seriously. So it can be concluded that the dense microstructure and high mullite content endow high bending strength of the sample fired at $1400^{\circ} \mathrm{C}$.

Figure 7 shows EDS mapping of the samples fired at various temperatures (e.g. 1400 and $1550^{\circ} \mathrm{C}$ ), and the EDS semiquantitative analysis results are collected in Table 2 . The mullite has the atomic ratio of $\mathrm{Al}$ to $\mathrm{Si}$ is $3: 1$, which is close to the general form of $3 \mathrm{Al}_{2} \mathrm{O}_{3} \cdot 2 \mathrm{SiO}_{2}$. However, apart from the dominant elements of $\mathrm{Al}, \mathrm{Si}$ and $\mathrm{O}$, the amorphous phase around the mullite crystals consists of $\mathrm{Ca}, \mathrm{Fe}, \mathrm{Ti}$, and $\mathrm{V}$ (Fig. 7), and the silica content in amorphous phase increases with the temperature (Table 2), suggesting the growth of mullite crystals is affected not only by the firing temperature, but also by the impurities of the waste gangue. Impurities as $\mathrm{TiO}_{2}$ and $\mathrm{Fe}_{2} \mathrm{O}_{3}$ have been suggested to facilitate mullite formation from waste gangue, which is similar with "a dissolution-precipitation process" growth mechanism of mullite in kaolin. ${ }^{12)-15)}$ Based on the experimental results, it can be concluded that using waste gangue as raw material is available for columnar mullite at low temperature of $1400^{\circ} \mathrm{C}$ due to the impurities e.g. $\mathrm{TiO}_{2}$ and $\mathrm{Fe}_{2} \mathrm{O}_{3}$ of waste gangue.

\section{Conclusions}

In conclusion, mullite phase were in-situ quantitatively prepared by introducing waste gangue replacement of the kaolin as main materials. Results show that the firing temperature affects mullite formation via impacting on its chemical composition and the viscosity of the liquid where mullite crystal grows from. The optimum refractory temperature to prepare mullite material using waste gangue is $1400^{\circ} \mathrm{C}$ and the optimum bending strength of 97.6 MPa is obtained due to the presence of interlocking structure constructed by mullite crystals across the plane. The new preparation method for mullite using waste gangue is desirable, especially for ceramic industry, due to low cost and the low mullitization temperature. The result would be helpful for the future development of the waste gangue in the ceramic industry.

Acknowledgement The present work was supported by the National Natural Science Foundation (Grant No. 51462016 and 51562013).

\section{References}

1) K. Boussois, N. Tessier-Doyen and P. Blanchart, J. Eur. Ceram. Soc., 33, 243-249 (2013).

2) W. E. Lee, G. P. Souza, C. J. Conville, T. Tarvornpanich and Y. Iqbal, J. Eur. Ceram. Soc., 28, 465-471 (2008).

3) S. M. Johnson and J. A. Pask, Am. Ceram. Soc. Bull., 61, 838842 (1982)

4) C. C. Harvey and H. H. Murray, Appl. Clay Sci., 11, 285-310 (1997).

5) X. Li, X. Gu, W. Dong and T. Luo, Mater. Sci. Forum, 848, 328-332 (2016).

6) A. Djemai, E. Balan, G. Morin, G. Hernandez, J. C. Labbe and J. P. Muller, J. Am. Ceram. Soc., 84, 1017-1024 (2001).

7) N. Sor, L. Aldon, J. C. Jumas, J. P. Laval and P. Blanchart, J. Am. Ceram. Soc., 86, 129-134 (2003).

8) H. Liu and Z. Liu, Resour. Conserv. Recy., 12, 1331-1340 (2010).

9) Z. Li, Z. Luo, X. Li, T. Liu, L. Guan, T. Wu and A. Lu, J. Porous Mater., 1, 231-238 (2016).

10) Y. Zhang, L. Xu, S. Seetharaman, L. Liu, X. Wang and Z. Zhang, Mater. Struct., 9, 2779-2793 (2015).

11) C. Wang, W. Ni, S. Zhang, S. Wang, G. Gai and W. Wang, Construct. Build. Mater., 1, 109-115 (2016).

12) Z. B. Du, M. X. Lu, J. Y. Ding, J. L. Li, X. L. Zhou and L. Lei, Coal Process. Compr. Util., 2, 47-50 (2010).

13) H. P. Ji, M. H. Fang, Z. H. Huang, K. Chen, Y. G. Xu, Y. G. Liu and J. T. Huang, Ceram. Int., 39, 6841-6846 (2013).

14) D. Cui, Refract. Mater, 45, 197-199 (2011).

15) X. Xu, X. Lao, J. Wu, Y. Zhang, X. Xu and K. Li, Appl. Clay Sci., 115, 76-86 (2015). 